\title{
A nutrition mathematical model to account for dietary supply and requirements of energy and nutrients for domesticated small ruminants: The development and evaluation of the Small Ruminant Nutrition System
}

\author{
Luis Orlindo Tedeschi ${ }^{1}$, Antonello Cannas ${ }^{2}$, Danny Gene Fox ${ }^{3}$ \\ ${ }^{1}$ Department of Animal Science, Texas A\&M University, College Station, TX 77845-2471 \\ ${ }^{2}$ Dipartimento di Scienze Zootecniche, Università di Sassari, 07100 Sassari, Italy \\ ${ }^{3}$ Department of Animal Science, Cornell University, Ithaca, NY 14853
}

ABSTRACT - A mechanistic model that predicts nutrient requirements and biological values of feeds for sheep (Cornell Net Carbohydrate and Protein System; CNCPS-S) was expanded to include goats and the name was changed to the Small Ruminant Nutrition System (SRNS). The SRNS uses animal and environmental factors to predict metabolizable energy (ME) and protein, and Ca and $\mathrm{P}$ requirements. Requirements for goats in the SRNS are predicted based on the equations developed for CNCPS-S, modified to account for specific requirements of goats, including maintenance, lactation, and pregnancy requirements, and body reserves. Feed biological values are predicted based on carbohydrate and protein fractions and their ruminal fermentation rates, forage, concentrate and liquid passage rates, and microbial growth. The evaluation of the SRNS for sheep using published papers (19 treatment means) indicated no mean bias $(\mathrm{MB} ; 1.1 \mathrm{~g} / 100 \mathrm{~g})$ and low root mean square prediction error (RMSPE; $3.6 \mathrm{~g} / 100 \mathrm{~g}$ ) when predicting dietary organic matter digestibility for diets not deficient in ruminal nitrogen. The SRNS accurately predicted gains and losses of shrunk body weight (SBW) of adult sheep $(15$ treatment means; MB $=5.8 \mathrm{~g} / \mathrm{d}$ and RMSPE $=30 \mathrm{~g} / \mathrm{d})$ when diets were not deficient in ruminal nitrogen. The SRNS for sheep had MB varying from -34 to $1 \mathrm{~g} / \mathrm{d}$ and RSME varying from 37 to $56 \mathrm{~g} / \mathrm{d}$ when predicting average daily gain (ADG) of growing lambs (42 treatment means). The evaluation of the SRNS for goats based on literature data showed accurate predictions for ADG of kids ( 31 treatment means; RMSEP $=32.5 \mathrm{~g} / \mathrm{d} ; \mathrm{r} 2=0.85$; concordance correlation coefficient, $\mathrm{CCC},=0.91)$, daily ME intake (21 treatment means; $\mathrm{RMSEP}=0.24 \mathrm{Mcal} / \mathrm{d} \mathrm{g} / \mathrm{d} ; \mathrm{r} 2=0.99 ; \mathrm{CCC}=0.99)$, and energy balance $(21$ treatment means; $\mathrm{RMSEP}=0.20 \mathrm{Mcal} / \mathrm{d} \mathrm{g} / \mathrm{d} ; \mathrm{r} 2=0.87 ; \mathrm{CCC}$ $=0.90$ ) of goats. In conclusion, the SRNS for sheep can accurately predict dietary organic matter digestibility, ADG of growing lambs and changes in SBW of mature sheep. The SRNS for goats is suitable for predicting ME intake and the energy balance of lactating and non-lactating adult goats and the ADG of kids of dairy, meat, and indigenous breeds. The SRNS model is available at http://nutritionmodels.tamu.edu.

\section{Introduction}

The most common domesticated small ruminants that have a worldwide economical impact are sheep and goats. The world population of sheep and goats increased from 1.35 billion in 1961 to 1.94 billion in 2006 (FAOSTAT, 2008); together, they always accounted for more than $52 \%$ of the domesticated ruminants (buffaloes, camels, cattle, goats, and sheep) in the world. The ratio of goats to sheep has been increasing. In 1961, the percentage of the sheep population over the domesticated ruminants was $41.6 \%$; by 2006 , it had declined to $31.3 \%$. However, the percentage of the goat population has increased from 14.7 to $23.8 \%$ for the same period. Even though the world population of sheep is greater than goats (1.1 versus 0.8 billion in 2006; respectively), the goat population has increased exponentially about $2.02 \% /$ year whereas the sheep population has fluctuated without a clear pattern; since 2001, it has consistently increased. In the US, the sheep population in January 2008 was 6.06 million after a decline of $2 \%$ from 2007 and the goat population in January 2008 was 3.02 million after an increase of 3\% from 2007 (USDANASS, 2008). These statistics indicate the importance of small ruminants and show a trend for goats being a major ruminant animal used for meat and milk production for years to come.

As world resources such as feed, land, and fresh water become limited or even scarce in some regions of the world, precise and accurate determination of energy and nutrients requirements by domesticated 
small ruminants is important to ensure minimal waste of these resources. Mathematical models have been proven to be powerful tools for improving animal performance while reducing nutrient excretion (TEDESCHI et al., 2005). This improved "nutrient accounting" is made possible by utilizing the accumulated scientific knowledge of requirement of energy and nutrients of the animals and the supply of energy and nutrients to develop models that predict animal requirements and diet utilization in each unique production scenario. It is through mathematical nutrition models that it is possible to integrate the scientific knowledge and to provide a simple and yet powerful tool to make decisions and create policies regarding the improvement of animal production.

The most critical step in mathematical modeling is to describe the purpose of a model. The second most important step is determining the appropriate mix of empirical and mechanistic representations of physiological functions, given the availability of development and evaluation datasets, inputs typically available and the benefits versus the risks of use associated with increased sensitivity (TEDESCHI et al., 2005).

Several mathematical models based on feeding standards or feed evaluation systems for sheep and goats have been developed by different countries. More specifically, the Agricultural and Food Research Council (AFRC, 1998, ARC, 1980); the Institut National de la Recherche Agronomique (INRA, 1989, 2007), the $\mathrm{E}$ (Kika) de la Garza Institute for Goat Research at Langston University, OK (LUO et al., 2004a, LUO et al., 2004b, LUO et al., 2004c, LUO et al., 2004d, e, LUO et al., 2004f, MOORE et al., 2004, SAHLU et al., 2004), and the National Research Council's nutrient requirements of small ruminants (NRC, 2007) are used worldwide. The INRA (1989, 2007) system is based on dairy and meat breeds for sheep and on dairy breeds for goats. The AFRC (1993) system is based on meat and wool breeds for sheep and on dairy breeds for goats. The NRC (2007) system, which for sheep uses CANNAS et al.(2004) and for goats it uses publications by the Institute for Goat Research, based the requirements on meat, wool, and dairy breeds for sheep and on dairy, meat, and indigenous breeds for goats.
The Small Ruminant Nutrition System (SRNS) model was developed based on the Cornell Net Carbohydrate and Protein System for sheep (CNCPS-S) framework (CANNAS et al., 2004). The SRNS model was modified to account for energy and protein requirements of sheep and goats under diverse practical conditions. Comparative information about energy and protein requirements for sheep (CANNAS, 2002) and for goats (CANNAS et al., 2008a) of current feeding systems has been extensively discussed. The objectives of this paper are to summarize the equations in the SRNS, and its evaluation with independent data, and to compare it with the most common feeding standard system used to predict energy and nutrient balances for small ruminants.

\section{Energy and Protein Requirements}

\section{Maintenance}

The NRC (1981) defined basal metabolic rate (BMR) as the amount of energy needed to maintain life processes of an animal (e.g. vital cellular activity, respiration, and blood circulation) under the fasting and resting state in a thermoneutral environment. The intake of energy below or above the BMR would result in a decrease or increase in body weight $(\mathbf{B W})$; respectively. CANNAS et al. (2004) modified the original maintenance submodel of the CNCPS (FOX et al., 2004) to account for the requirement of metabolizable energy (ME) for maintenance $\left(\mathbf{M E}_{\mathbf{M}}\right)$ for sheep. The modifications were based on recommendations of the ARC (1980) and CSIRO $(1990,2007)$ feeding standards (Equation [1]).

$M E_{M}=\frac{S B W^{0.75} \times a 1 \times S \times a 2 \times e^{(-0.03 \times A G E)}+0.09 \times M E I \times k_{M}+A C T+N E_{M C S}+U R E A}{k_{M}}$

Where shrunk BW (SBW) is defined as 96\% of full $\mathrm{BW}(\mathbf{F B W}), \mathrm{kg} ; \mathrm{ME}_{\mathrm{M}}$ is metabolizable energy required for maintenance, $\mathrm{Mcal} / \mathrm{d} ; \mathrm{SBW}^{0.75}$ is the metabolic SBW, kg; MEI is ME intake Mcal/d; ACT is net energy requirement for physical activity $\mathrm{Mcal} / \mathrm{d}$; $\mathrm{NE}_{\mathrm{MCS}}$ is net energy required for maintenance for cold stress as defined by CSIRO (1990, 2007), Mcal/d; UREA is net energy required to eliminate excess of nitrogen, $\mathrm{Kcal} / \mathrm{g}$; and $\mathrm{k}_{\mathrm{M}}$ is the partial efficiency of utilization of ME to NE for maintenance. The $\mathrm{S}$ factor is 1.15 for ram or billy. 
The energy required to eliminate excess of nitrogen as urea by cattle has been determined to be 7.3 $\mathrm{Kcal} / \mathrm{g}$ (TYRRELL et al., 1970). In sheep and goats, the recycled $\mathrm{N}$ can represent $15 \%$ of the $\mathrm{N}$ intake; however, large variations are found (mean of 6.58 and SD of 5.73 g/d) (BRUN-BELLUT, 1996). The amount of recycled $\mathrm{N}$ varies with physiological stages: end of pregnancy $>$ beginning of lactation $>$ drying periods receiving diets with high CP (BRUN-BELLUT, 1996). There has been some evidence that some species of goats (desert adapted Bedouin goats) may have a higher rate of $\mathrm{N}$ recycled (SILANIKOVE, 2000), but this could be related to slow passage rate. There is no clear evidence that goats recycle more $\mathrm{N}$ than sheep; therefore, the SRNS is similar between sheep and goats.

As discussed by CANNAS et al. (2004), al is the thermoneutral maintenance requirement, which is assumed to be $0.06214 \mathrm{Mcal}$ of $\mathrm{NE}_{\mathrm{M}} / \mathrm{kg}^{0.75}$ of shrunk BW (SBW) for all types of sheep and goats. Based on the work of SAHLU et al. (2004), a1 was assumed to be 0.0777 and 0.0652 Mcal of $\mathrm{NE}_{\mathrm{M}} / \mathrm{kg}^{0.75}$ of $\mathrm{SBW}$ for dairy goats and other goat breeds, respectively (CANNAS et al., 2007b). It has been shown that a1 is dependent on cattle breed (FOX et al., 2004, NRC, 2000); however, the SRNS assumes a constant value for sheep and only two different genotypes of goats despite some indication of breed differences. Several studies have shown conflicting values for sheep (NRC, 2007). For goats, FERNANDES et al. (2007) obtained 0.067 Mcal of $\mathrm{NE}_{\mathrm{M}} / \mathrm{kg}^{0.75}$ of SBW for Boer crossbred kids; they found values of $\mathrm{NE}_{\mathrm{M}}$ for goats in the literature varying from 62.5 to $85.1 \mathrm{Mcal}$ of $\mathrm{NE}_{\mathrm{M}} / \mathrm{kg}^{0.75}$ of $\mathrm{SBW}$ (FERNANDES et al., 2007). In the SRNS, the $\mathrm{k}_{\mathrm{M}}$ was assumed to be constant and equal to 0.644 .

The $\mathrm{S}$ factor in Equation [1] was excluded from the CNCPS-S model (CANNAS et al., 2006). This exclusion was supported by an updated discussion of the CSIRO (1990) calculations conducted by FREER et al. (1997). These authors concluded that experimental data could not support the sex adjustment as reported by FERRELL et al. (1979). Despite this update, the CSIRO (2007) model maintained the sex adjustment.

CANNAS et al. (2006) performed an evaluation of the SRNS for growing sheep based on several evaluation criteria discussed by TEDESCHI (2006). The evaluation database contained 42 treatment means of growing non-castrated male sheep from 9 studies. They concluded either the adjustment for age $\left(e^{-0.03 \times A g e}\right.$ term in Equation [1]) or the adjustment for ME required for level of production, which is due to increase in gut size because of increase intake $\left(0.09 \times M E I \times k_{M}\right.$ term in Equation [1]) should be removed to improve the predictability of the SRNS model. Therefore, if male or female lambs or kids are selected in the SRNS, the ME required for level of production is not used. In addition, recent evaluations showed that this factor should be removed to improve the predictability of the energy balance of adult goats by the SRNS model (CANNAS et al., 2007b).

The ACT in Equation [1] accounts for extra physical activity that is endured by grazing animals. For sheep it is compute as proposed by the ARC (1980) and adopted by CNCPS-S and SRNS (Equation [2]). For goats, the recommendations of the AFRC (1998) (Equation [3]) were adopted. As discussed by CSIRO (1990), energy expenditure for standing and changing positions are already accounted for by the BMR requirement and should not be added to Equations [2] or [3].

$A C T=(0.00062 \times$ Flat Distance $+0.00669 \times$ Sloped Distance $) \times F B W$

$A C T=(0.000836 \times$ Flat Distance $+0.00669 \times$ Sloped Distance $) \times F B W$

Where ACT is in Mcal of $\mathrm{NE}_{\mathrm{M}} / \mathrm{d}$; flat and sloped distances are in $\mathrm{km} / \mathrm{d}$; and $\mathrm{FBW}$ is full $\mathrm{BW}, \mathrm{kg}$.

Alternatively, CSIRO (1990) computed allowances of energy expenditure for grazing animals based on dry matter digestibility and availability of herbage of the pasture. The calculation was revised in the CSIRO (2007) publication.

Cold stress is calculated differently for sheep and goats (Equations [4] to Erro! Fonte de referência não encontrada.). The factor $\mathrm{z}$ (Equation Erro! Fonte de referência não encontrada.) is either 0.141 for sheep or 0.11 for goats. The factor $r$ (Equation Erro! Fonte de referência não encontrada.) is either 50 for lambs and kids or 120 for other types. Tissue insulation (TI) is assumed to be $1.3 \times 4.184=5.439$ ${ }^{\circ} \mathrm{C} \times \mathrm{m}^{2} \times \mathrm{d} / \mathrm{Mcal}$ and evaporative losses (E) is assumed to be $1.3 / 4.184=0.3107 \mathrm{Mcal} /\left(\mathrm{m}^{2} \times \mathrm{d}\right.$ ). If $\mathrm{NE}_{\mathrm{MCS}}$ (Equation 
[4]) is lower than zero, then $\mathrm{NE}_{\mathrm{MCS}}$ is zero. Equations [4] to Erro! Fonte de referência não encontrada. were based on the CSIRO $(1990$, 2007) recommendations.

$$
N E_{M C S}=\frac{S A \times(L C T-T C) \times k_{M}}{I N}
$$

$$
S A=0.09 \times S B W^{0.66}
$$

$$
L C T=39+E \times E I-\frac{H P \times I N}{S A}
$$

$$
H P=M E_{M}+\left(M E I-M E_{M}\right) \times\left(1-k_{G}\right)
$$

$I N=T I+\left[1-0.3 \times\left(1-e^{\frac{-1.5 \times \text { Rainfall }}{\text { Wool Depth }}}\right)\right] \times \mathrm{EI}$

$E I=W F \times \frac{4.184}{0.481+0.326 \times \sqrt{\text { Wind }}}+4.184 \times r \times \log \left(\frac{1}{W F}\right) \times(z-0.017 \times \sqrt{\text { Wind }})$

$W F=\frac{r}{r+\text { Wool Depth }}$

Where $\mathrm{NE}_{\mathrm{MCS}}$ is net energy required for maintenance due to cold stress, Mcal/d; SA is surface area, $\mathrm{m}^{2}$; LCT is lower critical temperature, ${ }^{\circ} \mathrm{C}$; $\mathrm{Tc}$ is current temperature, ${ }^{\circ} \mathrm{C}$; IN is total insulation, ${ }^{\circ} \mathrm{C} \times \mathrm{m}^{2} \times \mathrm{d} / \mathrm{Mcal}$; SBW is shrunk body weight, $\mathrm{kg}$; $\mathrm{E}$ is evaporative losses, $\mathrm{Mcal} /\left(\mathrm{m}^{2} \times \mathrm{d}\right)$; $\quad \mathrm{EI}$ is external insulation, ${ }^{\circ} \mathrm{C} \times \mathrm{m}^{2} \times \mathrm{d} / \mathrm{Mcal}$; HP is heat production, $\mathrm{Mcal} / \mathrm{d} ; \mathrm{ME}_{\mathrm{M}}$ is $\mathrm{ME}$ intake for maintenance, $\mathrm{Mcal} / \mathrm{d}$; MEI is ME intake, Mcal/d; $k_{\mathrm{G}}$ is partial efficiency of ME to NE for growth; TI is tissue insulation, ${ }^{\circ} \mathrm{C} \times \mathrm{m}^{2} \times \mathrm{d} / \mathrm{Mcal}$; WF is wool (sheep) or hair (goats) factor; Wind is $\mathrm{km} / \mathrm{h}$; Rainfall is $\mathrm{mm} / \mathrm{d}$; Wool or hair depth is $\mathrm{mm}$; $r$ and $\mathrm{z}$ are factors for sheep and goats.

The metabolizable protein (MP) for maintenance $\left(\mathbf{M P}_{\mathbf{M}}\right)$ requirements are the sum of dermal (wool) protein, urinary endogenous protein, and fecal endogenous protein losses (CSIRO, 1990, 2007). Equation [11] is used to compute $\mathrm{MP}_{\mathrm{M}}$. For goats, the first term in Equation [11] was modified to account for hair and scurf. Equation [12] is used to compute $\mathrm{MP}_{\mathrm{M}}$ for goats (CANNAS et al., 2007c).

$$
\begin{aligned}
& M P_{M}=\frac{\text { CleanWool }}{0.6 \times 365}+\frac{0.147 \times F B W+3.375}{0.67}+\frac{15.2 \times D M I}{0.67}[9] \\
& M P_{M}=0.1125 \times F B W^{0.75}+\frac{0.147 \times F B W+3.375}{0.67}+\frac{15.2 \times D M I}{0.67}[10]
\end{aligned}
$$

Where $\mathrm{MP}_{\mathrm{M}}$ is the metabolizable protein required for maintenance, $\mathrm{g} / \mathrm{d}$; the first term is scurf and wool CP requirement, $\mathrm{g} / \mathrm{d}$; the second term is the urinary endogenous $\mathrm{CP}, \mathrm{g} / \mathrm{d}$; the third term is the fecal endogenous $\mathrm{CP}, \mathrm{g} / \mathrm{d}$; Clean Wool is the clean wool produced per head, g/yr; FBW is full $\mathrm{BW}, \mathrm{kg}$; and DMI is dry matter intake, $\mathrm{kg} / \mathrm{d}$.

As discussed by CANNAS et al. (2004), the efficiency of conversion of MP to NP for urinary and fecal endogenous contributions was assumed to be 0.67 , which is the same coefficient used in the CNCPS model (FOX et al., 2004) and is similar to the 0.7 value used by CSIRO $(1990,2007)$. The hair requirement for goats was based on AFRC (1993) recommendation for scurf MP for goats (and cattle). The fecal endogenous CP requirement is variable; it increases as the dry matter intake (DMI) increases. This is consistent with the CNCPS model (FOX et al., 2004); however, the INRA (1989) and AFRC (1993) suggested that fecal endogenous was based on BW.

The NRC (2007) computed scurf and fiber MP requirement for wool sheep (Equation [13]) and hair sheep (Equation [14]) differently from the CNCPS-S and SRNS.

$$
\begin{aligned}
& \text { Scurf and Fiber } M P_{M}=\frac{0.2 \times B W^{0.6}}{0.6} \\
& \text { Scurf and Fiber } M P_{M}=\frac{\text { CleanWool }}{0.6 \times 365} \text { or } \frac{M E I \times 33.472 \times\left(S F W / F B W_{B C S 3.0}\right) \times W A A F}{0.6}
\end{aligned}
$$

$W A A F=\left\{\begin{array}{l}1 ; \text { if age }>24 \text { months } \\ \left(1+e^{-0.33 \times A G E}\right) \times \frac{F B W}{F B W_{B C S 3.0}}\end{array}\right.$

Where BW is body weight, kg; Clean Wool is the clean wool produced per head, g/yr; MEI is metabolizable energy intake, Mcal/d; SFW is standard final weight, $\mathrm{kg}$; $\mathrm{FBW}_{\mathrm{BCS} 3.0}$ is full $\mathrm{BW}$ (FBW) that would be achieved by a sheep/goat when skeletal development is complete and the empty body fat is approximately $25 \%, \mathrm{~kg}$; and WAAF is wool age adjustment factor. 


\section{Pregnancy}

The ME for pregnancy $\left(\mathrm{ME}_{\mathrm{P}}\right)$ requirements are estimated using the ARC (1980) equation as adapted by CSIRO (1990, 2007). The same equation was also adopted by the AFRC (1993). The $\mathrm{ME}_{\mathrm{P}}$ for sheep from $63 \mathrm{~d}$ after conception to delivery is shown in Equation [16]. Note that Equation [6] in CANNAS et al. (2004) had a wrong sign in the last term.

$M E_{P}=\frac{9.2438 \times L B W \times e^{\left(-11.465 \times e^{(-0.00643 \times t)}-0.00643 \times t\right)}}{k_{P}}$

Where $\mathrm{ME}_{\mathrm{P}}$ is the metabolizable energy required for pregnancy, Mcal/d; $\mathrm{t}$ is days of pregnancy; and LBW is the expected total lamb or lambs birth weight, $\mathrm{kg}$. The efficiency of utilization of ME for pregnancy $\left(\mathrm{k}_{\mathrm{P}}\right)$ is constant at 0.13 .

Equation [14] is also used by the SRNS model to estimate the $\mathrm{ME}_{\mathrm{P}}$ requirements for goats. When applied to this species, ME and NE requirements for pregnancy were very similar to those adopted by the NRC (2007) as discussed by CANNAS et al. (2008b).

Similarly, the MP for pregnancy $\left(\mathrm{MP}_{\mathrm{P}}\right)$ requirements are computed using the recommendations of CSIRO (1990, 2007), which were derived from the ARC (1980). Equation [17] lists the variables used to compute $\mathrm{MP}_{\mathrm{P}}$ using an efficiency of metabolizable to net protein of 0.70 .

$M P_{P}=\frac{1428.06 \times L B W \times e^{\left(-11.22 \times e^{(-0.00601 \times t)}-0.00601 \times t\right)}}{0.7}$

Where $\mathrm{MP}_{\mathrm{P}}$ is metabolizable protein required for pregnancy, $\mathrm{g} / \mathrm{d}$; $\mathrm{t}$ is days of pregnancy; and LBW is the expected total lamb or lambs birth weight, $\mathrm{kg}$. The efficiency of utilization of MP for pregnancy is constant at 0.7 .

Equation [15] is also used by the SRNS model for goats. When applied to this species, the NP pregnancy requirement predicted by this equation was similar to those predicted by the NRC (2007), while MP requirements were much lower (CANNAS et al., 2008a). This is likely to have occurred because the efficiency of utilization of MP to NP for gestation of 0.7 for sheep (CSIRO, 1990, 2007), which was adopted by the SRNS for goats, is about twice as large as that (0.33) adopted by the NRC (2001) for dairy cows and by the NRC (2007) for goats.

\section{Lactation}

The $\mathrm{ME}$ for lactation $\left(\mathrm{MP}_{\mathrm{L}}\right)$ requirement is computed based on the gross energy of milk and a constant efficiency of conversion of $\mathrm{ME}$ to $\mathrm{NE}$ for lactation $\left(\mathrm{K}_{\mathrm{L}}=0.644\right)$. The gross energy of milk is computed as shown by CANNAS et al. (2004) for sheep (Equation [18]) and by PULINA et al. (1992) for goats (Equation [19]). CSIRO $(1990,2007)$ uses a variable $\mathrm{k}_{\mathrm{L}}$ depending on the quality of the diet.

$$
\begin{aligned}
& M E_{L}=\frac{(251.73+89.64 \times P Q+37.85 \times(P P / 0.95)) \times Y n}{1000 \times k_{L}} \\
& M E_{L}=\frac{(289.72+71.93 \times P Q+48.28 \times(P P / 0.92)) \times Y n}{1000 \times k_{L}}
\end{aligned}
$$

Where $\mathrm{ME}_{\mathrm{L}}$ is metabolizable energy required for lactation, Mcal/d; Yn is actual milk yield at a particular day of lactation, $\mathrm{kg} / \mathrm{d}$; PQ is measured milk fat for a particular day of lactation, \%; and PP is measured true milk protein for a particular day of lactation, $\%$.

Based on the energy values published by AGUILEIRA (2001) and PULINA et al. (1992) and on the evaluation performed by CANNAS et al. (2007b), Equation [16] can also be used to predict $\mathrm{ME}_{\mathrm{L}}$ requirement for goats as long it is multiplied by 0.95 . This is because Equation [16] overpredicts $\mathrm{ME}_{\mathrm{L}}$ for goats by $5 \%$ on average. The original equations (shown by Equations [16] and [17]) used CP rather than true protein; the coefficients 0.95 and 0.92 were used to convert true protein to $\mathrm{CP}$ for sheep and goats, respectively.

Similarly, the MP for lactation $\left(\mathrm{MP}_{\mathrm{L}}\right)$ requirement for sheep and goats are computed from true milk protein content as shown in Equation [20].

$M P_{L}=\frac{10 \times P P \times Y n}{k_{P L}}$

Where $\mathrm{MP}_{\mathrm{L}}$ is metabolizable protein required for lactation, $\mathrm{g} / \mathrm{d}$; Yn is the actual milk yield on a particular day of lactation, $\mathrm{kg} / \mathrm{d}, \mathrm{PP}$ is the actual milk true protein 
for a specific day of lactation, \%; and $\mathrm{k}_{\mathrm{PL}}$ is the efficiency of MP to NP for pregnancy.

The coefficient for conversion of MP to NP $\left(\mathrm{k}_{\mathrm{PL}}\right)$ is suggested specifically for sheep by the INRA (1989) to be 0.58 . This efficiency is lower than that used for cattle and goats by most feeding systems. As pointed out by CANNAS et al. (2004), the low efficiency is likely because sheep have higher requirements than cattle for sulfur-containing amino acids, due to their wool production. The efficiency of $\mathrm{N}$ for lactation in cattle can be as high as $75 \%$ (RUIZ et al., 2002). Improvements in diet formulation might increase the efficiency of MP to NP for lactation. For goats, the SRNS model adopted the value 0.64 , as suggested by the INRA (1989).

\section{Growth}

The original requirements for growth of the SRNS were described by CANNAS et al. (2004). They were based on the requirements proposed by the CSIRO (1990, 2007) and modified by FREER et al. (1997). Based on comparisons between predicted and observed ADG of growing sheep performed by CANNAS et al. (2006), the original model (CANNAS et al., 2004) accounted for $79 \%$ of the variation $\left(\mathrm{r}^{2}\right)$, had $28.3 \%$ mean bias (MB), and the root of mean square error of prediction (RMSEP) was $70 \mathrm{~g} / \mathrm{d}$. The equations to predict $\mathrm{k}_{\mathrm{G}}$ of ARC (1980) and CSIRO $(1990,2007)$ yielded the following statistics: $r^{2}=81 \%, \mathrm{MB}=15.6 \%$, and RMSEP $=51 \mathrm{~g} / \mathrm{d}$; and $\mathrm{r}^{2}=68 \%, \mathrm{MB}=24.3 \%$, and $\mathrm{RMSEP}=68 \mathrm{~g} / \mathrm{d}$; respectively.

TEDESCHI et al. (2004) had suggested the use of a mechanistic equation to compute $\mathrm{k}_{\mathrm{G}}$ based on the proportion of retained energy as protein. Equation [21] has this relationship used to growing cattle, assuming average efficiency of deposition of fat and protein of 75 and $20 \%$; respectively.

$k_{G}=\frac{3}{4+11 \times R E p}$

Where $\mathrm{k}_{\mathrm{G}}$ is partial efficiency of ME to NE for growth and REp is the proportion of retained energy as protein.

The equation proposed by TEDESCHI et al. (2004) is more attractive than the empirical equations adopted by the NRC $(2000,2001)$, ARC (1980), and
CSIRO $(1990,2007)$ to compute partial efficiency of ME to NE for growth because from a biological point of view it accounts for the change in the proportion of protein (decrease) and fat (increase) in the gain as lambs and kids mature. Nonetheless, the empirical equations of NRC (2000, 2001), ARC (1980), and CSIRO (1990, 2007) may account for some of the post-digestive dietary effects not considered by the equation of TEDESCHI et al. (2004). In fact, we believe using a combination of body composition and energy content of the diet might be a better approach in computing the efficiency of utilization of energy for maintenance and growth. CANNAS et al. (2006) modified Equation [19] assuming average deposition efficiency of $27 \%$ for protein and $68 \%$ for fat for growing lambs (GRAHAM, 1980). The mechanistic equation modified for sheep and goats is shown in Equation [22].

$k_{G}=\frac{18.36}{27+41 \times R E p}$

Where $\mathrm{k}_{\mathrm{G}}$ is partial efficiency of ME to NE for growth and REp is the proportion of retained energy as protein.

When Equation [20] was evaluated with the same database developed by CANNAS et al. (2006), the SRNS explained $84 \%$ of the variation with a mean bias of $1 \mathrm{~g} / \mathrm{d}$ and RMSEP of $37 \mathrm{~g} / \mathrm{d}$, suggesting an improvement in growth predictions compared to empirical equations by NRC $(2000,2001), \operatorname{ARC}(1980)$, and CSIRO $(1990,2007)$ systems. The modified growth model for the SRNS, adopted both for lambs and kids, is shown in Equations [23] to [28].

$A D G=\frac{N E_{G} \times 1000}{0.92 \times E V G}$

$E V G=0.239 \times\left\{6.7+2 \times(L-1)+\frac{16.5-2 \times(L-1)}{1+e^{-6 \times(P-0.4)}}\right\}$

$\mathrm{NE}_{G}=M E_{G} \times k_{G}$

$R E p=\frac{R E_{\text {Prot }}}{R E_{\text {Prot }}+R E_{\text {Fat }}}$ 
$R E_{\text {Prot }}=\left[212-8 \times(L-1)-\frac{120-8 \times(L-1)}{1+e^{-6 \times(P-0.4)}}\right] \times 5.7$

$R E_{\text {Fat }}=\left[43+56 \times(L-1)+\frac{490-56 \times(L-1)}{1+e^{-6 \times(P-0.4)}}\right] \times 9.4$

Where ADG is average daily gain, $g / d ; \mathrm{NE}_{\mathrm{G}}$ is net energy available for growth, Mcal/d; EVG is energy content of gain; Mcal $/ \mathrm{kg} ; \mathrm{ME}_{\mathrm{G}}$ is metabolizable energy available for growth, Mcal/d; $\mathrm{k}_{\mathrm{G}}$ is partial efficiency of $\mathrm{ME}$ to $\mathrm{NE}_{\mathrm{G}}$; $\mathrm{RE}_{\mathrm{P}}$ is retained energy as protein; $\mathrm{RE}_{\text {Prot }}$ is retained energy from protein, $\mathrm{Mcal} / \mathrm{kg} ; \mathrm{RE}_{\mathrm{Fat}}$ is retained energy from fat, Mcal $/ \mathrm{kg}$; $\mathrm{L}$ is the intake above maintenance requirement factor ( $\mathrm{ME}$ intake/ $\left.M E_{M}-1\right)$; and $\mathrm{P}$ is degree of maturity (BW/standard $\mathrm{BW})$.

\section{Energy and Protein Reserves}

It is well established that during lactation, mammals undergo tremendous hormonal changes and nutrition partitioning in the body to support milk production. When the intake of energy is less than the requirement of energy (negative energy balance), most mammals mobilize body reserves to provide energy. The coordination of these metabolic processes have been thoroughly discussed (BAUMAN, 2000). EKNÆS et al. (2006) estimated changes in body reserves of 12 goats from kidding to 7 months of lactation using computer tomography. They reported that when energy supply from the pasture was not enough, the adipose tissue mass decreased by $3.5 \mathrm{~kg}$ on average, plasma concentrations of non-esterified fatty acids and acetoacetate were increased, and free fatty acids in milk was augmented. Therefore, nutrition models have to account for fluctuation in body reserves (energy and protein) to improve predictions of milk production.

The energy and protein reserves model was discussed by CANNAS et al. (2004). Body condition score (BCS), BW, and body composition are used to calculate changes in energy and protein reserves after first lambing, applying the same approach developed by the NRC (2000). The equation used to predict BW at any BCS for sheep breeds with different BW at BCS 2.5 (scale 0 to 5 ) is shown below. Empty BW (EBW) is $85.1 \%$ of SBW. Based on preliminary evaluations, Equation [29] can be used to predict BW at any BCS for goats (CANNAS et al., 2007c).
$F B W=(0.594+0.163 \times B C S) \times F B W_{B C S 2.5}$

Where FBW is the actual full body weight, $\mathrm{kg}$; $\mathrm{FBW}_{\mathrm{BCS} 2.5}$ is $\mathrm{FBW}$ at $\mathrm{BCS} 2.5, \mathrm{~kg}$; and $\mathrm{BCS}$ is current body condition score, 0 to 5 scale.

For lactating dairy cattle, MOE (1981) indicated that $1 \mathrm{Mcal}$ of reserve energy provides $0.82 \mathrm{Mcal}$ of $\mathrm{NE}_{\mathrm{L}}$ or $\mathrm{NE}_{\mathrm{M}}$. Protein mobilized from reserves is used for milk protein synthesis with an efficiency of 0.8 (CSIRO, 1990, 2007).

The empty body fat (EBF) for sheep is computed as shown in Equation [30] (CANNAS et al., 2004) and for goats it is computed as shown in Equation ([31]) based on NGWA's data et al. (2007).

$$
E B F=0.0269+0.0868 \times B C S
$$

$$
E B F=0.0289+0.0708 \times B C S
$$

TEDESCHI et al. (2006) indicated that current models predict ME- or MP-allowable milk production from the intake above requirements for maintenance, pregnancy, and growth without accounting for changes in BCS when predicting ME or MP balance. When adjustments were made to either ME- or MP-allowable milk due to changes in BCS, the accuracy and precision of the predictions were improved. These adjustments are not considered in the SRNS model because further evaluations are required for lactating sheep and goats.

\section{Wool}

CSIRO $(1990,2007)$ and NRC (2007) provided equations to compute energy requirement for wool growth. However, as suggested by CSIRO $(1990,2007)$ energy requirements for wool growth are in part already included in the ME requirements for maintenance (for a wool growth around $6 \mathrm{~g} / \mathrm{d}$ ). The extra energy required for breeds with high wool production is so small that it can be ignored. Thus, the SRNS has no predictions of energy requirement for wool or hair growth.

\section{Dietary Supply of Energy and Nutrients}

Predictions of dietary supply of energy and nutrients in the SRNS are consistent with the CNCPS-S as described by CANNAS et al. (2004). The main differences between the SRNS and the CNCPS for 
cattle (FOX et al., 2004) are passage rates of forages and concentrates that are based on CANNAS; VAN SOEST (2000) and the passage rate of liquids that was developed by CANNAS et al. (2004) (Equations [32][34]).

$$
\begin{aligned}
& k p_{\text {Forages }}=1.821 \times N D F I^{0.399} \times e^{0.046 \times C P} \\
& k p_{\text {Concentrates }}=1.572 \times k p_{\text {Forages }}-0.925 \\
& k p_{\text {Liquid }}=0.976 \times k p_{\text {Concentrate }}+3.516=1.534 \times k p_{\text {Forage }}+2.613
\end{aligned}
$$

Where $\mathrm{kp}$ is passage rate, $\% / \mathrm{h}$; NDFI is total dietary intake of neutral detergent fiber as a percentage of body weight; and CP is dietary concentration of crude protein, $\%$ of DM.

SEO et al. (2006a, 2006b) developed and evaluated new sets of predictive, empirical equations for passage rate in cattle using data developed with external markers. Random coefficient models were used to identify key independent predictor variables for passage rates of forages (Equation [35]), concentrates (Equation [36]), and liquid (Equation [37]). These new equations are yet to be evaluated for sheep and goats.

$K p_{\text {Forages }}=\frac{2.365+0.0214 \times F p B W+0.0734 \times C p B W+0.069 \times F D M I}{100}$

$K p_{\text {Concentrates }}=\frac{1.169+0.1375 \times F p B W+0.1721 \times C p B W}{100}$

$K p_{\text {Liquid }}=\frac{4.524+0.0223 \times F p B W+0.2046 \times C p B W+0.344 \times F D M I}{100}$

Where $\mathrm{Kp}$ is the passage rate, $\mathrm{h}^{-1}$; FpBW the forage DMI as a proportion of $\mathrm{BW}, \mathrm{g} / \mathrm{kg}$; $\mathrm{CpBW}$ the concentrate DMI as a proportion of BW and FDMI is the forage DMI, kg.

These Kp equations for forages, concentrates, and liquid explained $87 \%, 95 \%$ and $94 \%$, respectively of the variation in passage rates in the database used in equation development after adjustment for random study effect (SEO et al., 2006a). Several attempts have been made to derive empirical equations to determine passage rate of solids and liquids (CANNAS; VAN SOEST, 2000, FOX et al., 2004, LESCOAT; SAUVANT, 1995, NRC, 2000, 2001). These studies have similarly concluded that empirical models have limitations in predicting passage rate, and only explain a maximum of $40 \%$ of the variation (SEO et al., 2006a). Therefore, other types of modeling approaches are needed (ELLIS et al., 1994). SEO et al. (2007a, 2007b) developed a mechanistic, dynamic model to predict solid and liquid passage rates based on physiological and anatomical description of the rumen, animal information, and physicochemical characteristics of the feeds. They concluded the model was able to describe the factors that affect the dynamics of liquid and solids flow out of the rumen in dairy cattle. More work is needed for sheep and goats.

A second modification in developing the SRNS compared to the CNCPS (FOX et al., 2004) is the calculation of fecal crude protein $(\mathbf{C P})$. As pointed out by CANNAS et al. (2004), the first limitation in the calculation of the fecal crude protein (Equation [38]) is the calculation of endogenous $\mathrm{CP}\left(\mathrm{FCP}_{\mathrm{E}}\right.$; Equation [38] ). The intercept of the regression between digestible $\mathrm{CP}$ and $\mathrm{CP}$ intake was used to compute the endogenous $\mathrm{CP}$; however, it is comprised of endogenous $\mathrm{CP}$ and fecal microbial CP. The CNCPS accounted for microbial fecal CP separately $\left(\mathrm{FCP}_{\mathrm{M}}\right)$, leading to a double accounting of microbial fecal CP. The second limitation is the assumption of a fixed dietary indigestibility of $33 \%$ (CANNAS et al., 2004).

$\mathrm{FeCal}_{C P}=F C P_{U}+F C P_{M}+F C P_{E}=F C P_{U}+F C P_{M}+90 \times I D M$

Where $\mathrm{FCP}_{\mathrm{U}}$ is undegraded feed crude protein, $\mathrm{g} / \mathrm{d} ; \mathrm{FCP}_{\mathrm{M}}$ is fecal microbial crude protein, $\mathrm{g} / \mathrm{d} ; \mathrm{FCP}_{\mathrm{E}}$ is fecal endogenous crude protein, $\mathrm{g} / \mathrm{d}$.

To overcome these limitations, CANNAS et al. (2004) proposed two approaches. Only the approach used in the CNCPS-S model is discussed here. Equation [39] has the equation used in the SRNS to compute fecal CP.

Fecal $_{C P}=F C P_{U}+30 \times D M I$

Where $\mathrm{FCP}_{\mathrm{U}}$ is undegraded feed crude protein, $\mathrm{g} / \mathrm{d}$ and DMI is dry matter intake, $\mathrm{kg} / \mathrm{d}$.

Similar to the fecal CP calculation, the computation for fecal fat and ash were also changed in the SRNS as discussed by CANNAS et al. (2004). The problems are related to the double accounting of 
microbial fat and ash. Equations [40] and [41] contain the correct calculations.

$$
\begin{aligned}
& \text { Fecal }_{\text {Fat }}=\text { FFAT }_{U}+11.9 \times D M I \\
& \text { Fecal }_{\text {Ash }}=\text { FAsh }_{U}+17 \times D M I
\end{aligned}
$$

Where $\mathrm{FFAT}_{\mathrm{U}}$ is undegraded feed fat, $\mathrm{g} / \mathrm{d} ; \mathrm{FAsh}_{\mathrm{U}}$ is undegraded feed ash, $\mathrm{g} / \mathrm{d}$; and DMI is dry matter intake, $\mathrm{kg} / \mathrm{d}$.

Alternatively, another mechanistic approach would be to consider that only $15 \%$ of the $30 \mathrm{~g} / \mathrm{kg}$ of $\mathrm{DM}$, which is the intercept of the regression between digestible $\mathrm{CP}$ and $\mathrm{CP}$ intake, was endogenous contributions $(85 \%$ was from microbial origin; VAN SOEST, 1994). Therefore, it would imply $4.5 \mathrm{~g}$ of microbial CP/ $\mathrm{kg}$ of DMI (Equation [42]), $1.79 \mathrm{~g}$ of microbial fat $/ \mathrm{kg}$ of DMI (Equation [43]), and $2.55 \mathrm{~g}$ of microbial ash $/ \mathrm{kg}$ of DMI (Equation [44]).

$$
\begin{aligned}
& F e c a l_{C P}=F C P_{U}+F C P_{M}+F C P_{E}=F C P_{U}+F C P_{M}+4.5 \times D M I \\
& F e c a l_{F a t}=F F A T_{U}+F F A T_{M}+F F A T_{E}=F F A T_{U}+F F A T_{M}+1.79 \times D M I
\end{aligned}
$$

$\mathrm{Fecal}_{\text {Ash }}=F A s h_{U}+F A s h_{M}+F A s h_{E}=F A s h_{U}+F A s h_{M}+2.55 \times D M I$

These forms allow for fecal microbial contribution changes with diets and also corrects for the double-accounting of microbial fecal CP in the CNCPS (FOX et al., 2004).

\section{Model Evaluations}

The NRC (2007) conducted an evaluation of the CNCPS-S as published by CANNAS et al. (2004). For growing and finishing sheep, the NRC (2007) developed a database containing 156 observations (1,876 sheep) from 31 references. When the feed biological value was not provided by the references, the NRC (2007) assumed the values reported by the NRC (2000, 2001). Without any requirement adjustments for $\mathrm{ME}_{\mathrm{M}}$, the CNCPS-S accounted for $70 \%$ of the variation of the observed ADG with mean bias of $37 \mathrm{~g} / \mathrm{d}$. When the visceral organ component of the $\mathrm{ME}_{\mathrm{M}}$ requirement was removed $\left(0.09 \times M E I \times k_{M}\right.$ term in Equation [1]), the CNCPS-S had a lower mean bias $(10 \mathrm{~g} / \mathrm{d})$ than the original equation, but similar $\mathrm{r}^{2}(0.70)$. The NRC (2007) also tested the predictions of the NRC (1985) system and concluded the CNCPS-S and the NRC (1985) were accurate and precise in predicting energy requirements for growing sheep. However, because the CNCPS-S included the calculation for protein requirements and supplies, calculations for BW changes, and several classes of sheep, the NRC (2007) adopted it to develop their nutrient requirement tables. The NRC (2007) evaluation of the CNCPS-S predictions for lactating sheep contained 6 publications with 19 observations. The CNCPS-S predicted $\mathrm{NE}_{\mathrm{L}}$ accurately when changes in ADG were accounted for. The $\mathrm{r}^{2}$ was 0.82 and mean bias was $0.174 \mathrm{Mcal} / \mathrm{d}$. This finding supports the need to adjust for changes in BCS or BW to accurately predict ME or MP available for lactation as discussed by TEDESCHI et al. (2006). To evaluate the MP calculations of the CNCPS-S for growing or finishing sheep, the NRC (2007) collected information on 174 treatment means, representing 335 sheep, from 31 references. A regression between MP available and used yielded an $\mathrm{r}^{2}$ of 0.88 and mean bias of $0.9 \mathrm{~g} / \mathrm{d}$. The NRC (2007) recommended the CNCPS-S for calculating MP requirements of growing or finishing sheep. Furthermore, the NRC (2007) recommended the use of the CNCPS-S for non-pregnant and early- or mid-gestation ewes, lactating ewes, and late gestating ewes.

For goats, the NRC (2007) adopted the data summarized by Sahlu and collaborators (LUO et al., 2004a, LUO et al., 2004b, LUO et al., 2004c, LUO et al., 2004d, e, LUO et al., 2004f, MOORE et al., 2004, NSAHLAI et al., 2004a, b, SAHLU et al., 2004) for energy and protein requirements.

CANNAS et al. (2007b) evaluated the SRNS using five published studies on lactating does and female wethers (21 treatment means). The predictions of daily MEI and milk net energy were highly accurate when DMI was known. The SRNS underpredicted the energy balance of lactating does (mean bias of $-0.31 \mathrm{Mcal} / \mathrm{d}$; RMSPE of $0.40 \mathrm{Mcal} / \mathrm{d}$; and $r^{2}$ of 0.79). This is similar to findings reported by CANNAS et al. (2006) when evaluating the SRNS ability to predict growth of growing lambs. Both under-predictions by the SRNS model for growing animals might be related to the $0.09 \times \mathrm{MEI} \times \mathrm{k}_{\mathrm{M}}$ term of Equation [1] as discussed above. CANNAS et al. (2007b) reported that when this term was removed for the calculation of $\mathrm{ME}_{\mathrm{M}}$, the predictions of energy balance of goats by the SRNS were remarkably 
improved (mean bias of $-0.08 \mathrm{Mcal} / \mathrm{d}$; RMSPE of $0.20 \mathrm{Mcal} / \mathrm{d}$; and $\mathrm{r}^{2}$ of 0.87 ).

The evaluation of the SRNS for growing kids were performed by CANNAS et al. (2007a) using eight publications with goat breeds for milk, meat, and indigenous ( $\mathrm{N}=31$ data points). The evaluation showed that the mean and the systematic bias were very small and the RMSEP was smaller (mean bias of $6.4 \mathrm{~g} / \mathrm{d}$; RMSPE of $32.5 \mathrm{~g} / \mathrm{d}$; and $\mathrm{r}^{2}$ of 0.85 ) than that reported when the SRNS predictions of the ADG of lambs were evaluated (CANNAS et al., 2006). When the predictions were based on the SRNS estimates of MEI and on the ME requirements for maintenance and gain of NRC (2007), the RMSEP was increased, mainly due to a fairly large and significant systematic bias, which made the regression line statistically different from the equivalence line (mean bias of $7.2 \mathrm{~g} / \mathrm{d}$; RMSPE of 34.9 $\mathrm{g} / \mathrm{d}$; and $\mathrm{r}^{2}$ of 0.86 ) (CANNAS et al., 2007a). In particular, the NRC (2007) model overpredicted the ADG at high observed ADG and underpredicted the ADG at low observed values. This can be explained by the fact that this model uses a fixed value for the cost of gain, regardless the $\mathrm{BW}$ or the relative size of the kids.

\section{Recommendations for Future Work}

Several recommendations for future work were discussed by SAHLU et al. (2004) for goats, including composition of BW change, partial efficiency of NE to $\mathrm{ME}_{\mathrm{M}}$, energy expenditure for physical activity, ruminally undegraded protein, and maintenance losses of protein.

As shown by CANNAS et al. (2006), the adjustment of $\mathrm{ME}_{\mathrm{M}}$ for intake above maintenance requirements (level of production) may inflate the $\mathrm{ME}_{\mathrm{M}}$ requirement and consequently underpredict $\mathrm{ADG}$ of growing sheep. The NRC (2000) explicitly adjusts $\mathrm{ME}_{\mathrm{M}}$ based on BCS using a linear relationship between BCS and $\mathrm{NE}_{\mathrm{M}}$; for every change in BCS unit above or below $5, \mathrm{NE}_{\mathrm{M}}$ is changed by $5 \%$. CSIRO $(1990,2007)$ implicitly adjusts $\mathrm{ME}_{\mathrm{M}}$ based on $\mathrm{ME}$ intake above maintenance requirements (Equation [1]), assuming a $9 \%$ increase in $\mathrm{ME}_{\mathrm{M}}$ per Mcal of $\mathrm{ME}$ above maintenance. WILLIAMS; JENKINS (2003) also suggested adjustments to heat production to support ME intake above maintenance. It is possible the adjustment for $\mathrm{ME}_{\mathrm{M}}$ for animals consuming $\mathrm{ME}$ above maintenance is likely double accounting ME required if it was determined on animals consuming above maintenance. Furthermore, the efficiency of use of ME to NE for animals below BCS 5 might be greater than animal above BCS 5 ( 1 to 9 scale) for the same change in BCS; that means that a change of BCS from 3 to 4 would yield a larger value for ME than a change of BCS from 6 to 7. The duration of the adjustment might be different for animals above or below BCS 5 for the same change in BCS; that means a change of BCS from 3 to 4 might impact $\mathrm{NE}_{\mathrm{M}}$ for a longer period of time than a change of BCS from 6 to 7. The current nutrition models do not account for these issues mainly because they were designed to be static and deterministic (TEDESCHI et al., 2005). Thus, the real importance of this adjustment factor needs to be re-evaluated. In particular it is not clear why it seems to be important for adult sheep but not for adult goats.

As discussed in the growth section, CANNAS et al. (2006) modified an equation developed by TEDESCHI et al. (2004) to compute $\mathrm{k}_{\mathrm{G}}$ for sheep. Equation [20] is also used for goats. This equation is based on composition of the gain and has no provisions to account for diet fermentability and volatile fatty acids produced in the rumen. The equations used by the NRC (2000) to compute $\mathrm{NE}_{\mathrm{M}}$ and $\mathrm{NE}_{\mathrm{G}}$ are based on dietary ME concentration. There is a disconnection between these two approaches in predicting partial efficiency for growth; in fact, they are two different viewpoints to solve the same problem: What is the amount of energy available for growth? Thus the first approach uses composition of gain to compute ME required for growth $\mathrm{NE}$ and the other one uses dietary energy availability to compute ME available for growth NE. A mechanistic system is needed to incorporate both approaches. As more propionate is generated in the rumen, there is an increase in glucose via gluconeogenesis and at the same time there is a decrease in the oxidation of amino acids via gluconeogenesis, sparing amino acids for protein deposition. Therefore, at the same gain composition of protein, if the ratio of propionate to acetate is greater, the partial efficiency of $\mathrm{ME}$ to $\mathrm{NE}_{\mathrm{G}}$ might be augmented due to reduction in the oxidation of amino acids to supply energy.

Future work is needed to account for physically effective neutral detergent fiber (peNDF) of the diet and small ruminants' ability to select feed on chewing activity, ruminal $\mathrm{pH}$, and fiber fermentation in the 
rumen. Because small ruminants (mainly goats) are able to select the more nutritious parts of the diet (HOFFMANN, 1989) for consumption, it is possible that ruminal $\mathrm{pH}$ might be lower, impacting fiber digestibility compared to large ruminants (e.g. cattle). At the same time, goats eat concentrates in small, frequent meals and are more able to avoid acidosis than sheep (ABIJAOUDÉ et al., 2000). Also, the passage rate is faster in goats likely due to greater saliva production. The peNDF and fiber digestibility of the SRNS were developed and evaluated with cattle and dew data on sheep, but there is lack of evaluation with goats.

The integration of nutrition and production models would assist in the optimization of small ruminant production scenarios given the dynamics of herd size and economic feasibility. Because of the increased production of meat and dairy from small ruminants (sheep and goats) worldwide, decision support systems could be developed to assist in determining optimal nutrition and production arrangements given the availability of resources (GUIMARÃES, 2007, GUIMARÃES et al., 2007, GUIMARÃES et al., 2008a, b). This system would help in maintaining profitability under different scenarios of production.

\section{Conclusions}

Small ruminants have slowly increased their importance in the food production chain around the world. Recent trends indicate that goats may supersede the sheep population within the next 5 years. Accurate and precise predictions of requirement and supply of energy and nutrients is necessary to rationally and adequately manage production of sheep and goats. Current evaluations of the Small Ruminant Nutrition System have indicated the model has fulfilled the criteria for adoption for several types of productions of sheep and goats. Further work is needed to improve the acceptability and predictions of models based on the SRNS framework.

\section{Literature Cited}

ABIJAOUDÉ, J.A., MORAND-FEHR, P., TESSIER, J., et al. 2000. Influence of forage : concentrate ratio and type of starch in the diet on feeding behaviour, dietary preferences, digestion, metabolism and performance of dairy goats in mid lactation. Animal Science. 71:359-368.

AFRC. 1993. Energy and Protein Requirements of Ruminants. Wallingford, UK: Agricultural and Food Research Council. CAB International, $159 \mathrm{p}$.

AFRC. 1998. The Nutrition of Goats. Wallingford, UK: CAB International,

AGUILERA, J.F. 2001. Aportaciones al conocimiento de la nutrición energética de pequeños rumiantes, con particular referencia al ganado caprino. Archivos de Zootecnia. 50:565596.

ARC. 1980. The Nutrient Requirements of Ruminant Livestock. London: Agricultural Research Council. The Gresham Press, $351 \mathrm{p}$.

BAUMAN, D.E. 2000. Regulation of nutrient partitioning during lactation: homeostasis and homeorhesis revisited. In: CRONJÉ, P.B. Ruminant Physiology: Digestion, Metabolism, Growth and Reproduction. New York: CABI Publishing, p. 311-328.

BRUN-BELLUT, J. 1996. Urea recycling in the rumen of dairy goats: effects of physiological stage and composition of intake. Small Ruminant Research. 23:83-90.

CANNAS, A. 2002. Energy and protein requirements. In: PULINA, G. Dairy Sheep Feeding and Nutrition. Bologna, Italy: Avenue Media, p. 55-81.

CANNAS, A., ATZORI, A.S., BOE, F., et al. 2008a. Energy and protein requirements of goats. In: CANNAS, A., PULINA, G. Dairy Goats, Feeding and Nutrition. Cambridge, MA: CAB International, p. 118-146.

CANNAS, A., TEDESCHI, L.O., ATZORI, A.S., et al. 2006. Prediction of energy requirements for growing sheep with the Cornell Net Carbohydrate and Protein System. In: DIJKSTRA, J. Modeling Nutrient Utilization in Farm Animals. Cambridge, MA: CABI Publishing, p. 99-113.

CANNAS, A., TEDESCHI, L.O., ATZORI, A.S., et al. Prediction of the growth rate of kids with the Small Ruminant Nutrition System. In: Annual Meeting of the Brazilian Society of Animal Science, 44, Jaboticabal, SP, Brazil. July 27, 2007. Anais. SBZ, 2007a. 1-3 p.

CANNAS, A., TEDESCHI, L.O., ATZORI, A.S., et al. The Small Ruminant Nutrition System (SRNS) model for prediction of energy and protein requirements of goats and sheep. In: American Society of Animal Science, Indianapolis, IN. Anais. ASAS, 2008b. (Submitted) p.

CANNAS, A., TEDESCHI, L.O., FOX, D.G. Prediction of metabolizable energy intake and energy balance of goats with the Small Ruminant Nutrition System. In: International Symposium on Energy and Protein Metabolism and Nutrition, 2nd, Vichy, France. September 9-13, 2007. Anais. 2007b. 569-570 p.

CANNAS, A., TEDESCHI, L.O., FOX, D.G. The Small Ruminant Nutrition System: development of a goat submodel. In: American Society of Animal Science, San Antonio, TX. Anais. ASAS-ADSA, 2007c. 505 p.

CANNAS, A., TEDESCHI, L.O., FOX, D.G., et al. 2004. A mechanistic model for predicting the nutrient requirements and feed biological values for sheep. Journal of Animal Science. 82:149-169.

CANNAS, A., VAN SOEST, P.J. 2000. Allometric models to predict rumen passage rate in domestic ruminants. In: MCNAMARA, J.P., FRANCE, J., BEEVER, D.E. Modeling Nutrient Utilization in Farm Animals. Wallingford, Oxon, UK: CABI Publishing, p. 49-62. 
CSIRO. 1990. Feeding Standards for Australian Livestock. Ruminants. Melbourne, Australia: Commonwealth Scientific and Industrial Research Organization, $266 \mathrm{p}$.

CSIRO. 2007. Nutrient Requirements of Domesticated Ruminants. Collingwood, VIC: Commonwealth Scientific and Industrial Research Organization, 270 p.

EKNÆS, M., KOLSTAD, K., VOLDEN, H., et al. 2006. Changes in body reserves and milk quality throughout lactation in dairy goats. Small Ruminant Research. 63:1-11.

ELLIS, W.C., MATIS, J.H., HILL, T.M., et al. 1994. Methodology for estimating digestion and passage kinetics of forages. In: FAHEY JR., G.C., COLLINS, M., MERTENS, D.R., et al. Forage quality, evaluation, and utilization. Madison, WI: American Society of Agronomy, p. 682-756.

FAOSTAT. 2008. Food and Agriculture Organization of the United Nations. Available: http://faostat.fao.org/site/573/default.aspx. Accessed May 18, 2008.

FERNANDES, M.H.M.R., RESENDE, K.T., TEDESCHI, L.O., et al. 2007. Energy and protein requirements for maintenance and growth of Boer crossbred kids. Journal of Animal Science. 85:1014-1023.

FERRELL, C.L., CROUSE, J.D., FIELD, R.A., et al. 1979. Effects of sex, diet and stage of growth upon energy utilization by lambs. Journal of Animal Science. 49:790-801.

FOX, D.G., TEDESCHI, L.O., TYLUTKI, T.P., et al. 2004. The Cornell Net Carbohydrate and Protein System model for evaluating herd nutrition and nutrient excretion. Animal Feed Science and Technology. 112:29-78.

FREER, M., MOORE, A.D., DONNELLY, J.R. 1997. GRAZPLAN: decision support systems for Australian grazing enterprises-II. The animal biology model for feed intake, production and reproduction and the GrazFeed DSS. Ag. Syst. 54(1):77-126.

GRAHAM, R.M. 1980. Variation in energy and nitrogen utilization by sheep between weaning and maturity. Australian Journal of Agricultural Research. 31(2):335-345.

GUIMARÃES, V.P. Modeling a dairy goat farm using a system dynamics approach. Viçosa, MG, Brazil, 2007. 199 p. Ph.D. Dissertation - Federal University of Viçosa, 2007.

GUIMARÃES, V.P., TEDESCHI, L.O., RODRIGUES, M.T. Development of a dairy goat model to study the impact of management strategies on the dynamics of herds. In: Southern section of American Society of Animal Science, Mobile, AL. Anais. ASAS-ADSA, 2007. 39 p.

GUIMARÃES, V.P., TEDESCHI, L.O., RODRIGUES, M.T. A dairy goat model to study the impact of management strategies on herd dynamics. In: International Conference on Goats, Queretaro, MX. Anais. International Goat Association, 2008a. (Submitted) p.

GUIMARÃES, V.P., TEDESCHI, L.O., RODRIGUES, M.T. Modelling the impact of breeding seasons in the dynamics of dairy goat herds. production and economical evaluations. In: International Conference on Goats, Queretaro, MX. Anais. International Goat Association, 2008b. (Submitted) p.

HOFFMANN, R.R. 1989. Evolutionary steps of ecophysiological adaptation and diversification of ruminants: a comparative view of their digestive system. Oecologia. 78:443-457.

INRA. 1989. Ruminant nutrition. Recommended allowances and feed tables. Montrouge, France: Institut National de la Recherche Agronomique, John Libbey Eurotext, 389 p.
INRA. 2007. Alimentation des bovins, ovins et caprins. Besoins des animaux. Valeurs des aliments. Versailles, France: Editions Quae, 307 p.

LESCOAT, P., SAUVANT, D. 1995. Development of a mechanistic model for rumen digestion validated using the duodenal flux of amino acids. Reproduction, Nutrition, Development. 35:45-70.

LUO, J., GOETSCH, A.L., MOORE, J.E., et al. 2004a. Prediction of endogenous urinary nitrogen of goats. Small Ruminant Research. 53:293-308.

LUO, J., GOETSCH, A.L., NSAHLAI, I.V., et al. 2004b. Maintenance energy requirements of goats: predictions based on observations of heat and recovered energy. Small Ruminant Research. 53:221-230.

LUO, J., GOETSCH, A.L., NSAHLAI, I.V., et al. 2004c. Voluntary feed intake by lactating, Angora, growing and mature goats. Small Ruminant Research. 53:357-378.

LUO, J., GOETSCH, A.L., NSAHLAI, I.V., et al. 2004d. Metabolizable protein requirements for maintenance and gain of growing goats. Small Ruminant Research. 53:309-326.

LUO, J., GOETSCH, A.L., NSAHLAI, I.V., et al. 2004e. Prediction of metabolizable energy and protein requirements for maintenance, gain and fiber growth of Angora goats. Small Ruminant Research. 53:339-356.

LUO, J., GOETSCH, A.L., SAHLU, T., et al. 2004f. Prediction of metabolizable energy requirements for maintenance and gain of preweaning, growing and mature goats. Small Ruminant Research. 53:231-252.

MOE, P.W. 1981. Energy metabolism of dairy cattle. Journal of Dairy Science. 64:1120-1139.

MOORE, J.E., GOETSCH, A.L., LUO, J., et al. 2004. Prediction of fecal crude protein excretion of goats. Small Ruminant Research. 53:275-292.

NGWA, A.T., DAWSON, L.J., PUCHALA, R., et al. 2007. Urea space and body condition score to predict body composition of meat goats. Small Ruminant Research. 73:27-36.

NRC. 1981. Nutritional Energetics of Domestic Animals and Glossary of Energy Terms. Washington, DC.: Natl. Acad. Press,

NRC. 1985. Nutrient Requirements of Sheep. 6th. ed. Washington, DC: National Academy Press,

NRC. 2000. Nutrient Requirements of Beef Cattle. updated 7th. ed. Washington, DC: National Academy Press, 242 p.

NRC. 2001. Nutrient Requirements of Dairy Cattle. 7th. ed. Washington, DC: National Academy Press, $381 \mathrm{p}$.

NRC. 2007. Nutrient Requirements of Small Ruminants: Sheep, Goats, Cervids, and New World Camelids. 6th. ed. Washington, DC: National Academy Press, $384 \mathrm{p}$.

NSAHLAI, I.V., GOETSCH, A.L., LUO, J., et al. 2004a. Metabolizable energy requirements of lactating goats. Small Ruminant Research. 53:253-273.

NSAHLAI, I.V., GOETSCH, A.L., LUO, J., et al. 2004b. Metabolizable protein requirements of lactating goats. Small Ruminant Research. 53:327-337.

PULINA, G., CANNAS, A., SERRA, A., et al. 1992. Determinazione e stima del valore energetico di latte di capre di razza Sarda. Atti della Società Italiana di Scienze Veterinarie. 45:1779-1781.

RUIZ, R., TEDESCHI, L.O., MARINI, J.C., et al. 2002. The effect of a ruminal nitrogen $(\mathrm{N})$ deficiency in dairy cows: evaluation of the Cornell net carbohydrate and protein system ruminal $\mathrm{N}$ deficiency adjustment. Journal of Dairy Science. 85:2986-2999. 
SAHLU, T., GOETSCH, A.L., LUO, J., et al. 2004. Nutrient requirements of goats: developed equations, other considerations and future research to improve them. Small Ruminant Research. 53:191-219.

SEO, S., LANZAS, C., TEDESCHI, L.O., et al. 2007a. Development of a mechanistic model to represent the dynamics of liquid flow out of the rumen and to predict rate of passage of liquid in dairy cattle. Journal of Dairy Science. 90:840-855.

SEO, S., LANZAS, C., TEDESCHI, L.O., et al. 2007b. Development of a mechanistic model to represent the dynamics of particle flow out of the rumen and to predict rate of passage rate of particles in dairy cattle. Journal of Dairy Science.(Submitted).

SEO, S., TEDESCHI, L.O., SCHWAB, C.G., et al. $2006 \mathrm{a}$. Development and evaluation of empirical equations to predict feed passage rate in cattle. Animal Feed Science and Technology. 128:67-83.

SEO, S., TEDESCHI, L.O., SCHWAB, C.G., et al. 2006 b. Evaluation of the passage rate equations in the 2001 Dairy NRC Model. Journal of Dairy Science. 89:2327-2342.

SILANIKOVE, N. 2000. The physiological basis of adaptation in goats to harsh environments. Small Ruminant Research. 35:181-193.

TEDESCHI, L.O. 2006. Assessment of the adequacy of mathematical models. Ag. Syst. 89:225-247.

TEDESCHI, L.O., FOX, D.G., GUIROY, P.J. 2004. A decision support system to improve individual cattle management. 1. A mechanistic, dynamic model for animal growth. Ag. Syst. 79:171-204.
TEDESCHI, L.O., FOX, D.G., SAINZ, R.D., et al. 2005. Using mathematical models in ruminant nutrition. Scientia Agricola. 62(1):76-91.

TEDESCHI, L.O., SEO, S., FOX, D.G., et al. 2006. Accounting for energy and protein reserve changes in predicting dietallowable milk production in cattle. Journal of Dairy Science. 89:4795-4807.

TYRRELL, H.F., MOE, P.W., FLATT, W.P. Influence of excess protein intake on energy metabolism of the dairy cow. In: Proceedings of Energy Metabolism of Farm Animals, 5, Vitznau, Switzerland. September 1970. Anais. EAAP, EAAP Publications 1970. 69-72 p.

USDA-NASS. 2008. National Agricultural Statistics Service, Agricultural Statistics Board, Sheep and Goats. Available: http://usda.mannlib.cornell.edu/MannUsda/viewDocumentInf o.do?documentID=1145. Accessed May 25, 2008.

VAN SOEST, P.J. 1994. Nutritional Ecology of the Ruminant. 2nd. ed. Ithaca, NY: Comstock Publishing Associates, $476 \mathrm{p}$.

WILLIAMS, C.B., JENKINS, T.G. 2003. A dynamic model of metabolizable energy utilization in growing and mature cattle. I. Metabolizable energy utilization for maintenance and support metabolism. Journal of Animal Science. 81:1371-1381. 